\title{
Respon Hama Wereng Coklat Nilaparvata lugens Stal. (Hemiptera: Delphacidae) Terhadap Ketahanan Dan Kerentanan Varietas Padi
}

\author{
Response of Brown Planthopper Nilaparvata lugens Stal. (Hemiptera: Delphacidae) on the \\ Resistance and Vulnerability of Rice Varieties
}

\section{Rein Estefanus Senewe ${ }^{1, *}$, Silvia Permatasari ${ }^{2}$ dan Marietje Pesireron ${ }^{1}$}

\author{
${ }^{1}$ Balai Pengkajian Teknologi Pertanian (BPTP) Maluku, Jln. Chr. Soplanit Rumahtiga Ambon, 97233 Indonesia \\ ${ }^{2}$ Jurusan Budidaya Pertanian, Fakultas Pertanian Universitas Andalas, Limau Manis Padang, 25163 Sumatera Barat \\ Indonesia
}

*E-mail Penulis Korespondesi: reinsenewe@gmail.com

Tanggal submisi: 06 Desember 2019; Tanggal penerimaan: 30 Mei 2020

\begin{abstract}
Brown planthopper (BPH) is one of the important pest insects that attack rice plants, which indirectly becomes a vector for the spread of grassy dwarf and empty dwarf diseases caused by viruses, and can consume a lot of food in a short time so that it can cause damage explosions and great losses. The aim of this study was to compare the eating response of brown planthopper to resistant and vulnerable rice varieties through the measurement of secreted honeydews. The study was conducted at the Toxicology Laboratory, Department of Plant Protection, Faculty of Agriculture, Bogor Agricultural University. Rice seedlings for honeydew testing were 30 days after sowing. Testing was done by infesting 3 female BPH into a plastic cage with filter paper (Whatman No.40 $9 \mathrm{~cm}$ in diameter) placed on the bottom, which had been sprayed with a solution of Ninhydrin $0.01 \mathrm{mg} / \mathrm{ml}$ in acetone. The treatment consisted of 3 rice varieties (Ciherang, IR-64 dan Pelita) on each ovened and non-ovened filter paper, with three replicates so that a total of 18 treatments were used by infesting each with the 3 female BPH nymphs. Whereas, 3 treatments with non-ovened papers, with 3 replicates, were infested with 3 female BPH imago each. So that the treatments involved a total of 27 feeding tubes. Honeydews released by $\mathrm{BPH}$ that ate on the test varieties for 24 hours were collected on filter papers and formed blue/purple spots. The extent of the honeydew spots formed was measured and analyzed. The results showed that the average value of phloem consumption in Ciherang, IR-64, and Pelita rice varieties showed that these three varieties were very susceptible to BPH sucking pests. The more food nutrients sucked by BPH pests from rice plants, the greater the number of honeydew spots and the wider the honeydew spots that were produced. The areas of honeydew spots of Pelita variety was $33.78 \mathrm{~m}^{2}$, IR-64 $28.26 \mathrm{~mm}^{2}$, and Ciherang $22.44 \mathrm{~mm}^{2}$, respectively. Pelita rice varieties had a high susceptibility to BPH pests when compared to Ciherang and IR-64 because Pelita does not have resistance genes to BPH pests.
\end{abstract}

Keywords: Ciherang, IR-64, Pelita, planthopper, rice, honeydew

\section{ABSTRAK}

Wereng batang coklat (WBC) merupakan salah satu serangga hama penting yang menyerang tanaman padi, yang secara tidak langsung menjadi vektor bagi penyebaran penyakit kerdil rumput dan kerdil hampa oleh virus, serta dapat mengkonsumsi makanan yang banyak dalam waktu singkat sehingga dapat menimbulkan ledakan kerusakan dan kerugian yang besar. Penelitian ini bertujuan untuk membandingkan respon makan WBC pada varietas padi tahan dan rentan melalui pengukuran embun madu yang disekresikan. Penelitian dilaksanakan di Laboratorium Toksikologi, Departemen Proteksi Tanaman Fakultas Pertanian, Institut Pertanian Bogor. Bibit padi untuk pengujian embun madu digunakan saat berumur 30 hari setelah semai. Pengujian dengan menginfestasikan WBC betina ke dalam kurungan plastik yang di bagian bawahnya diletakkan kertas saring (Whatman No. 40 berdiameter $9 \mathrm{~cm}$ ) yang telah disemprot dengan larutan Ninhidrin $0,01 \mathrm{mg} / \mathrm{mL}$ aseton. Perlakuan yang terdiri dari 3 varietas padi (Ciherang, IR-64 dan Pelita) pada masing-masing kertas saring oven dan tidak oven dan dengan tiga ulangan sehingga total terdapat 18 perlakuan dengan menginfestasikan masing-masing 3 ekor nimfa betina WBC. Sedangkan pada 3 perlakuan kertas saring tanpa oven, dengan tiga ulangan, yang diinfestasikan masing-masing berupa 3 ekor imago betina WBC. Sehingga total perlakuan seluruhnya meliputi sebanyak 27 tabung makan. Embun madu yang dikeluarkan oleh WBC yang makan pada varietas uji selama 24 jam 
tertampung pada kertas saring dan membentuk bercak berwarna biru/ungu. Luas bercak embun madu yang terbentuk diukur dan dianalisis. Hasil penelitian menunjukkan bahwa nilai rata-rata tingkat konsumsi floem pada varietas padi Ciherang, IR-64 dan Pelita, menunjukkan bahwa ketiga varietas ini sangat rentan terhadap hama pengisap WBC. Semakin banyak nutrisi makanan yang disedot oleh hama WBC dari tanaman padi, maka semakin banyak jumlah spot bercak honeydew dan semakin luas spot bercak honeydew yang dihasilkan. Luas spot untuk varietas Pelita adalah 33,78 $\mathrm{m}^{2}$, IR$6428,26 \mathrm{~mm}^{2}$, dan Ciherang 22,44 $\mathrm{mm}^{2}$. Varietas padi Pelita memiliki kerentanan yang tinggi terhadap hama WBC, bila dibandingkan dengan varietas Ciherang dan IR-64, karena varietas Pelita ini tidak memiliki gen ketahanan terhadap hama WBC.

Kata kunci: Ciherang, honeydew IR-64, padi, Pelita, wereng

\section{PENDAHULUAN}

Serangga wereng batang coklat (WBC) Nilaparvata lugens Stal. (Hemiptera: Delphacidae) merupakan salah satu hama penting yang menyerang tanaman padi. Hama ini merusak padi secara langsung dengan menghisap cairan dari batang hingga tanaman kering dan mati. Serangan WBC di lapangan berfluktuatif, mulai ringan sampai mencapai puncak perkembangannya saat terjadi ledakan yang menimbulkan puso/mati terbakar (hopperburn). Wereng batang coklat menyerang langsung tanaman padi dengan mengisap cairan sel tanaman sehingga tanaman menjadi kering. Serangan tidak langsungnya yaitu wereng dapat mentransfer virus yang berbahaya bagi tanaman padi, yaitu virus kerdil hampa, virus kerdil rumput tipe 1, dan virus kerdil rumput tipe 2 .

Hubungan serangga hama WBC dengan tanaman padi akibat dari serangga dapat mengenali atau merasakan keberadaan senyawa kimia dalam jumlah/konsentrasi rendah di dalam makanannya. Senyawa-senyawa yang telah dikenal baik oleh serangga akan dijadikan tanda bahwa tanaman tersebut adalah inang mereka dan kebanyakan senyawa-senyawa yang telah dikenal dijadikan sebagai penarik (atraktan). Sebaliknya kehadiran senyawa-senyawa yang belum dikenal (foreign compounds) dapat mengakibatkan penolakan pada serangga. Inilah yang mendasari mengapa serangga memilih inang tertentu dan tidak memilih inang yang lain. Penolakan serangga terhadap kehadiran senyawa-senyawa kimia tertentu dapat dimanfaatkan untuk dikaji lebih mendalam tentang aspek pengendalian serangga hama (Dadang dan Prijono 2008).

Senyawa-senyawa yang terkandung di dalam tanaman, dapat menunjukkan berbagai macam aktivitas biologi pada serangga seperti penghambatan/penolakan makan, penolakan peneluran, penghambatan pertumbuhan dan perkembangan, kematian dan lain-lain (Dadang dan Prijono 2008). Nonpreference merupakan sifat tanaman yang menyebabkan suatu serangga menjauhi atau tidak menyenangi suatu tanaman baik sebagai pakan atau sebagai tempat peletakan telur. Menurut Kogan (1982) istilah yang lebih tepat digunakan untuk sifat ini adalah antixenosis yang berarti menolak tamu. Antixenosis dapat dikelompokkan menjadi penolakan kimiawi atau antixenosis kimiawi dan penolakan morfologi atau antixenosis morfologi.
Antixenosis kimiawi terjadi karena tanaman mengandung allelokimia yang menolak kehadiran serangga pada tanaman. Antixenosis morfologi, ketahanan tanaman disini terbawa oleh adanya sifat-sifat struktural atau morfologi tanaman yang dapat menghalangi terjadinya proses makan dan peletakan telur yang normal.

Ketahanan beberapa varietas tanaman padi dapat dianalisis berdasarkan sekresi honeydew yang dikeluarkan oleh WBC untuk menentukan juga suatu populasi/biotipe wereng coklat. Varietas-varietas padi yang banyak di kembangkan seperti Ciherang, IR-64 dan Pelita menjadi objek dalam penelitian ini. Berdasarkan hal ini, penelitian ini bertujuan untuk mempelajari perbandingan respon makan WBC pada varietas padi tahan dan rentan melalui pengukuran embun madu yang disekresikan.

\section{METODE PENELITIAN}

Benih padi untuk pengujian embun madu saat berumur 30 hari setelah semai. Pengujian dengan menginfestasi 3 ekor WBC betina ke dalam kurungan plastik (tabung makan) yang menyungkup bagian batang sebelah bawah dari tanaman yang diuji (Gambar 1). Dibagian bawah tabung makan ini diletakkan kertas saring (Whatman No. 40 berdiameter $9 \mathrm{~cm}$ ) yang telah disemprot dengan larutan ninhidrin $0,01 \mathrm{mg} / \mathrm{mL}$ aseton. Perlakuan yang terdiri dari 3 varietas padi pada masingmasing kertas saring oven dan tidak oven dan ulangan 3 kali sehingga total 18 perlakuan dengan menggunakan/menginfestasi masing-masing 3 ekor nimfa betina WBC.

Sedangkan pada 3 perlakuan kertas saring tanpa oven (ulangan tiga kali) yang diinfestasi hanya masingmasing 3 ekor imago betina WBC. Sehingga total perlakuan seluruhnya sebanyak 27 tabung makan. Embun madu yang dikeluarkan oleh WBC yang makan pada varietas uji selama 24 jam. Embun madu yang disekresikan oleh WBC tertampung pada kertas saring dan membentuk bercak berwarna biru/ungu. Luas bercak embun madu yang terbentuk diukur dan dihitung. Luas area ini diduga berkolerasi positif dengan banyaknya cairan floem yang dihisap oleh serangga (Gambar 2). Analisis data meliputi perbandingan luas area dan ratarata luas area honeydew. 


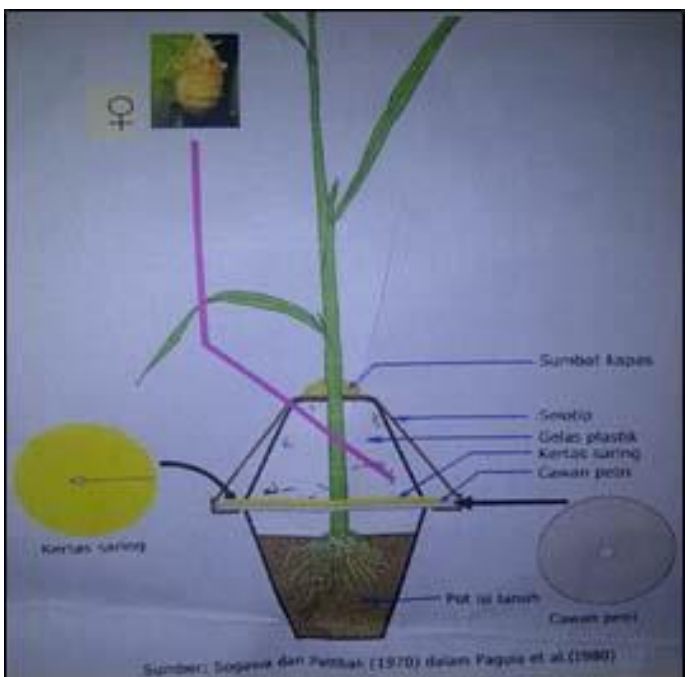

Gambar 1. Pengujian embun madu (Paguila et al., 1980)

\section{HASIL PEMBAHASAN}

Nilaparvata lugens Stal. (Hemiptera: Delphacidae), atau WBC merupakan salah satu hama penting yang menyerang tanaman padi. Hama ini merusak padi secara langsung dengan menghisap cairan dari batang hingga tanaman kering dan mati. Secara tidak langsung WBC menjadi vektor bagi penyebaran penyakit kerdil rumput dan kerdil hampa yang disebabkan oleh virus (Bahagiawati dan Habib, 2005), sehingga pada saat menusuk dapat menularkan penyakit Virus Kerdil Rumput (rice grassy stunt virus = VKR) tipe 1 dan tipe 2 dan Virus Kerdil Hampa (rice ragged stunt virus =VKH) (Baehaki, 2011). Hama ini menyerang berbagai varietas tanaman padi khususnya varietas unggul tipe baru (VUTB) serta padi hibrida yang diketahui rentan terhadap serangan organisme pengganggu tanaman, serta padi varietas unggul baru (VUB) (Baehaki, 2008 dalam Rahmini et al., 2012).

Sumber pakan dan keberadaan musuh alami dalam suatu ekosistem dan habitat tanaman padi dapat mempengaruhi kelimpahan serangga WBC. Keberadaan musuh alami dapat memengaruhi populasi WBC yang berada pada lahan sawah (Gunawan et al., 2015). Musuh alami baik parasitoid, predator dan pathogen secara alami bekerja tergantung pada kepadatan serangga herbivore. WBC termasuk serangga bertipe r-strategi, artinya populasi serangga dapat menemukan habitatnya dengan cepat, berkembang biak dengan cepat dan mampu menggunakan sumber daya makanan yang baik sebelum serangga lain ikut berkompetisi, mempunyai sifat menyebar dengan cepat ke habitat yang baru sebelum habitat lain tidak berguna lagi. WBC dapat memanfaatkan makanan yang banyak dalam waktu singkat sehingga dapat menimbulkan ledakan dan kerugian yang tidak sedikit (Baehaki, 2011). WBC hidup dengan mengisap cairan floem tanaman padi, yang mengakibatkan daun berubah warna menjadi kuning oranye sebelum menjadi coklat, mengering dan kemudian mati. Kondisi ini, disebut "hopperburn" karena tanaman terlihat seperti terbakar (Cagampang et al., 1974 dalam Rahmini et al., 2012). WBC dapat menyebabkan puso pada fase vegetatif maupun generatif tanaman, yaitu pada daun, batang, dan malai hingga menjadi kering kecoklatan seperti terbakar. Penggunaan varietas padi rentan merupakan salah satu faktor yang menyebabkan kemunculan WBC di lahan sawah (Rahmini et al., 2012).

Tabel 1. Perbandingan rata-rata luas area bercak honeydew imago dan nimfa betina WBC pada kertas saring tanpa di oven pada varietas padi Ciherang, Pelita dan IR 64

\begin{tabular}{ccc}
\hline \multirow{2}{*}{ Jenis } & \multicolumn{2}{c}{$\begin{array}{c}\text { Luas Bercak honeydew } \\
\left(\mathrm{mm}^{2}\right)\end{array}$} \\
\cline { 2 - 3 } Padi & $\begin{array}{c}\text { Investasi imago } \\
\text { WBC }\end{array}$ & $\begin{array}{c}\text { Investasi nimfa } \\
\text { WBC }\end{array}$ \\
\hline Ciherang & $7,83 \pm 5,97$ & $37,04 \pm 44,25$ \\
IR-64 & $38,25 \pm 35,20$ & $18,26 \pm 9,24$ \\
Pelita & $66,89 \pm 65,38$ & $0,67 \pm 0,58$ \\
\hline
\end{tabular}

Keterangan: Angka yang diikuti dengan huruf yang sama tidak berbeda nyata taraf 5\% uji DMRT.

Untuk mengetahui ketahanan tanaman padi yang diuji terhadap suatu populasi/biotipe wereng coklat, didasarkan pada luas ekskreta (honeydew) yang dikeluarkan oleh wereng coklat yang makan pada varietas uji selama 24 jam. Hasil penelitian menunjukkan bahwa dari ketiga varietas padi (Ciherang, IR-64 dan Pelita) memiliki bercak embun madu (honeydew) (Gambar 2) yang nampak tertampung pada kertas saring atau membentuk bercak berwarna biru/ungu. Bercak honeydew dipindai dan kemudian diukur luas areanya $\left(\mathrm{mm}^{2}\right)$.

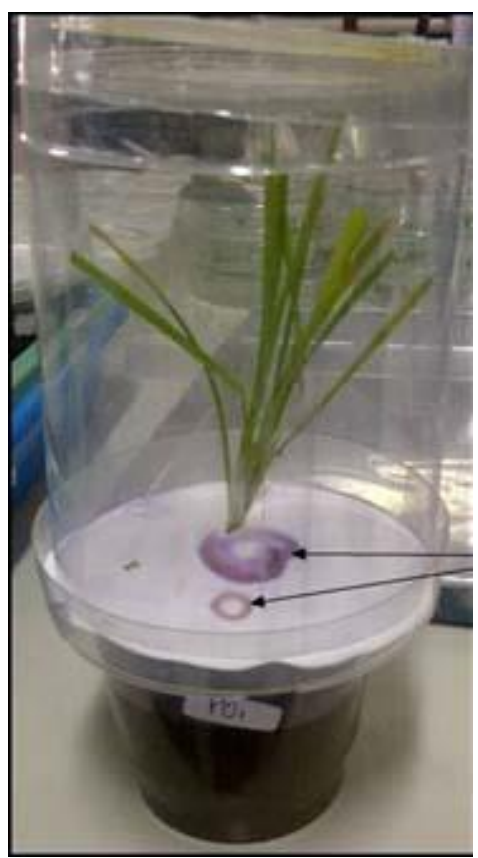

Gambar 2. Sekresi yang dikeluarkan oleh WBC berupa embun madu 
Luas area bercak honeydew ini diduga berkorelasi positif dengan banyaknya cairan pembuluh tapis (floem) tanaman padi yang disedot oleh serangga serta hubungannya dengan ketahanan varietas padi (Manzila $e t$ al 2000). Luas bercak embun madu pada kertas indikator berbanding terbalik dengan ketahanan suatu varietas. Semakin besar luas bercak embun madu pada kertas indikator maka semakin rentan suatu varietas terhadap serangan WBC. Sebaliknya jika luas bercak semakin kecil maka varietas tersebut dikatakan tahan.

Hasil penelitian berupa honeydew atau embun madu yang disekresikan baik imago maupun nimfa hama WBC pada varietas padi Ciherang, IR-64 dan Pelita yang tertampung pada kertas saring yang tanpa di oven menunjukkan hasil tidak berbeda nyata. Nimfa hama WBC yang makan pada varietas padi Pelita mengeluarkan ekskreta/bercak honeydew dengan ratarata ukuran relatif besar, yaitu $66,89 \mathrm{~mm}^{2}$ dibandingkan dengan luas ekskreta yang dikeluarkan WBC varietas padi IR-64 yaitu $38,25 \mathrm{~mm}^{2}$ dan varietas padi Ciherang $7,83 \mathrm{~mm}^{2}$. Berdasarkan nilai rata-rata tingkat konsumsi floem pada varietas padi Ciherang, IR-64 dan Pelita, menunjukkan bahwa ketiga varietas ini sangat rentan terhadap hama pengisap WBC (Tabel 2). Varietas padi Pelita bila dibandingkan dengan varietas Ciherang dan IR-64, memiliki kerentanan yang tinggi terhadap hama WBC karena varietas Pelita ini tidak memiliki gen ketahanan terhadap hama WBC.

Tabel 2. Rata-rata luas area bercak honeydew nimfa betina WBC pada kertas saring di oven dan tanpa oven pada varietas padi Ciherang, Pelita dan IR 64

\begin{tabular}{ccc}
\hline \multirow{2}{*}{ Jenis Padi } & \multicolumn{2}{c}{$\begin{array}{c}\text { Luas Bercak honeydew } \\
\left(\mathrm{mm}^{2}\right)\end{array}$} \\
\cline { 2 - 3 } Perlakuan & $\begin{array}{c}\text { Kertas Saring di } \\
\text { Oven }\end{array}$ & $\begin{array}{c}\text { Kertas Saring } \\
\text { Tanpa di Oven }\end{array}$ \\
\hline Ciherang & $26,17 \pm 27,80$ & $7,83 \pm 5,97$ \\
IR- 64 & $21,83 \pm 17,06$ & $38,25 \pm 35,20$ \\
Pelita & $54,67 \pm 73,28$ & $66,89 \pm 65,38$ \\
\hline
\end{tabular}

Keterangan: Angka yang diikuti dengan huruf yang sama tidak berbeda nyata taraf $5 \%$ uji DMRT.

Tabel 3. Efektivitas makan hama WBC pada varietas padi Ciherang, Pelita dan IR-64 berdasarkan analisis bercak honeydew

\begin{tabular}{cc}
\hline Jenis Padi Perlakuan & $\begin{array}{c}\text { Luas Bercak honeydew } \\
\left(\mathrm{mm}^{2}\right)\end{array}$ \\
\hline Ciherang & $22,44 \mathrm{a}$ \\
IR- 64 & $28,26 \mathrm{a}$ \\
Pelita & $33,78 \mathrm{a}$ \\
\hline
\end{tabular}

Keterangan: Angka yang diikuti dengan huruf yang sama tidak berbeda nyata taraf 5\% uji DMRT.

Sehingga kalau dilihat interaksi antara perlakuan secara keseluruhan, menujukkan bahwa varietas Pelita memiliki total luas bercak honeydew sebesar 33,78 (Tabel 3). Embun madu yang tersekresi dari serangga
WBC tersebut berbasis floem menunjukkan tanaman rentan, sedangkan yang transparan menunjukkan tanaman tahan. Senyawa ninhidrin menghasilkn produk berwarna ungu pada semua asam amino yang mempunyai gugus L- $\alpha$-amino bebas, bearti uji positif terhadap ninhidrin yang ditandai adanya warna ungu yang muncul. Semakin banyak nutrisi makanan yang disedot oleh hama WBC dari tanaman padi, maka semakin banyak jumlah spot bercak dan semakin luas spot yang dihasilkan (Harini, 2013).

Faktor ketidakmurnian hama WBC juga merupakan faktor penentu, karena untuk menjamin kemurnian biotipe WBC tidak hanya memerlukan populasi WBC yang murni, namun juga sarana pemeliharaan WBC lainnya seperti rumah kaca yang kedap serangga untuk memperbanyak tanaman makanan WBC dan memperbanyak WBC itu sendiri. Sehingga diharapkan di masa mendatang, penyaringan varietas/galur padi untuk ketahanan terhadap WBC tidak memerlukan populasi murni apabila dilihat bahwa populasi WBC di lapang reaksinya hanya sedikit berbeda satu dengan yang lain (Suyono et al., 2000).

Pengontrolan pada fase vegetative tanaman padi sangat penting, karena fase vegetatif sebelum pembentukan bulir, populasi WBC akan bertambah dimana dalam fase ini tanaman padi diduga cenderung menyerap lebih banyak unsur nitrogen untuk pembentukan protein, dilain pihak sebagai sumber nutrisi bagi WBC (Rashid et al., 2016). Penggunaan pupuk nitrogen yang berlebihan dan tidak tepat dalam waktu aplikasi atau sesuai dengan kondisi pertanaman padi, dapat memicu peningkatan populasi WBC (Kadja, 2015).

Pola perkembangan hama wereng coklat yang ditunjang dengan lingkungan baik musim hujan maupun musim kemarau dapat memicu kerusakan tanaman tinggi, serta secara cepat dapat menularkan penyakit virus kerdil hampa dan virus kerdil rumput. Hama wereng coklat mampu melemahkan kerja insektisida yang dianggap ampuh sebelumnya (Baehaki 2012). Perkembangan dan tantangan perakitan varietas padi yang tahan hama WBC terus dikembangkan seiring dengan perkembangan biotipe baru hama ini.

\section{KESIMPULAN}

Kesimpulan-kesimpulan dari penelitian adalah:

1. Berdasarkan nilai rata-rata tingkat konsumsi floem pada varietas padi Ciherang, IR-64 dan Pelita, menunjukkan bahwa ketiga varietas ini sangat rentan terhadap hama pengisap WBC.

2. Semakin banyak nutrisi makanan yang disedot oleh hama WBC dari tanaman padi, maka semakin banyak jumlah bercak honeydew dan semakin luas bercak honeydew yang dihasilkan.

3. Luas bercak honeydew varietas Pelita adalah 33,78 $\mathrm{m}^{2}$, IR-64 28,26 mm² dan Ciherang 22,44 $\mathrm{mm}^{2}$.

4. Varietas padi Pelita memiliki kerentanan yang tinggi terhadap hama WBC, bila dibandingkan dengan varietas Ciherang dan IR-64, karena varietas Pelita 
ini tidak memiliki gen ketahanan terhadap hama WBC.

\section{DAFTAR PUSTAKA}

Baehaki, S.E. 2011. Strategi fundamental pengendalian hama wereng batang coklat dalam pengamanan. Pengembangan Inovasi Pertanian 4: 63-75.

Baehaki, S.E. 2012. Perkembangan Biotipe Hama Wereng Coklat pada Tanaman Padi. IPTEK TANAMAN PANGAN 7 (1): 1-17

Bahagiawati, dan H. Rijzaani. 2005. Pengelompokan biotipe wereng cokelat berdasarkan hasil PCRRAPD clustering of brown planthopper biotype based on RAPD-PCR. Hayati 12: 1-6.

Dadang, dan D. Prijono. 2008. Insektisida Nabati: Prinsip, Pemanfaatan, dan Pengembangan. Departemen Proteksi Tanaman. Fakultas Pertanian, Institut Pertanian Bogor.

Gunawan, C.S.E., G. Mudjiono, dan L.P. Astuti. 2015. Kelimpahan populasi wereng batang coklat Nilaparvata lugens Stal. (Homoptera: Delphacidae) dan laba-laba pada budidaya tanaman padi dengan penerapan pengendalian hama terpadu dan konvensional. Jurnal HPT 3: 117-122.

Kadja, D.H. 2015. Pengaruh jenis pupuk dan tinggi genangan air terhadap perkembangan populasi wereng batang padi coklat pada tanaman padi. Jurnal Ilmu Pertanian 18: 18-23. DOI: 10.22146/ipas.6171

Kogan, M. 1982. Plant Resistance In Pest Management. In: Metcalf, R.L. and W.H. Luckmann (Editors).
Introduction to Insect Pest Management. Second Edition. New York: John Wiley \& Sons. Pp. 93-134.

Manzila, I., H. Rijzaani, dan Bahagiawati. 2000. Pemurnian Wereng Coklat Biotipe Laboratorium. Prosiding Seminar Hasil Penelitian Rintisan dan Bioteknologi Tanaman.

Paguia, P., M.D. Pathak, and E.A. Heinrichs. 1980. Honeydew excretion measurement techniques for determining differential feeding activity of biotypes of Nilaparvata lugens on rice varieties. Journal of Economic Entomology 73: 35-40. DOI: $10.1093 /$ jee/73.1.35

Rahmini, P. Hidayat, E.S. Ratna, I.W. Winasa, dan S. Manuwoto. 2012. Respon biologi wereng batang coklat terhadap biokimia tanaman padi. Penelitian Pertanian Tanaman Pangan 31: 117123.

Rashid, Md.M., M. Jahan, and K.S. Islam. 2016. Impact of nitrogen, phosphorus and potassium on brown planthopper and tolerance of its host rice plant. Rice Science 23: 119-131. DOI: 10.1016/j.rsci.2016.04.001

Harini, S.A., S. Sai Kumar, P. Balaravi, R. Sharma, A. Dass, and V. Shenoy. 2013. Biotechnology Evaluation of rice genotypes for brown planthopper (BPH) resistance using molecular markers and phenotypic methods. African Journal of Biotechnology 12: 2515-2525.

Suyono, M., I. Sutrisno, D. Suwenda, dan Isak. 2000. Karakterisasi populasi WBC dengan varietas diferensial. Laporan Hasil Penelitian. Balitbio 1999/2000. 